DE DE GRUYTER OPEN
Journal of Intercultural Management

Vol. 6, No. 4, part II, December 2014, pp. 49-66

DOI 10.2478/joim-2014-0056

Małgorzata Bartosik-Purgat ${ }^{1}$

Uniwersytet Ekonomiczny w Poznaniu

Alicja Hadryś-Nowak ${ }^{1}$

Uniwersytet Ekonomiczny w Poznaniu

\title{
The Impact of the Family-owned Businesses Specificity on the Dominance of the Cultural Features in their Organizational Structures - Theoretical Approach
}

\begin{abstract}
The purpose of this article is to show how the specifics of family businesses (the "familiness") affects the company's organization culture. In other words, the article aim is to identify the specific impact of family businesses on certain cultural traits identified in international studies and in the literature as „,culture's dimensions „..Literature analysis and the results of previous research on family businesses let the authors to specify a list of characteristics that "possession”, in the most comprehensive way, describes the specifics of the family business. Based on the literature review authors decided to select some dimensions - cultural traits that are particularly distinctive and noticeable in family businesses, such as: universalism/particularism and status assigned/achieved according to Trompenaars and Hampden-Turner, power distance and femininity/masculinity according to Hofstede, pro-partnership/pro-transaction according to Gesteland. Combining the specificity of family and selected cultural dimensions authors found that in family businesses predominate particularistic behavior, hierarchies, there is also a high power distance but with the advantage of setting pro-partnership and female characteristics. In family businesses, there is also a predominance of assigned status. Conducted analysis leads authors to the conclusion that family businesses, regardless of their country and its cultural differences in which they operate, have common features,
\end{abstract}

1 m.purgat@ue.poznan.pl, alicja.hadrys@ue.poznan.pl 
which are expressed in the intensity of specific cultural characteristics. The article is a theoretical analysis and will be the basis for forward empirical research.

Keywords: family companies, organizational culture, national culture, foreign markets

\section{Introduction}

The family-owned businesses development in the international markets is conditioned by many factors, amongst which, besides of the most important economic factors, it is pointed on the cultural of the certain country. The values arising from the tradition and other constant elements of the national culture, including the important role of the family in the every individual life, have its influence on the fact, that ex. Italy or Spain are characterized with the one of the highest percentage in Europe of the family-owned businesses in the general number of the private enterprises. It is from these European countries originate numerous multigenerational family-owned business known worldwide, such as, Benneton, Adolfo Dominguez or PUIG. In the Asiatic or Arabian countries the situation is similar, here the meaning of the family and respect for its oldest members is extremely important, the dominant business position belongs to the family-owned businesses [Pant, Rajadhyaksha 1996, p. 812].

The purpose of this paper is to indicate the manner of influence of the "familiness" in the family-owned businesses on the cultural elements of its organization. In other words, the authors make an attempt of indication the influence of the familyowned businesses specificity on the "power" of certain cultural features marked in the international researches and often specified in the literature as the "culture dimensions".

\section{The family-owned business specificity}

It is difficult to find in the literature unequivocal definition of the family-owned business, which would be preferred by all researches in this field. This is, inter alia, due to the engagement of many different academic disciplines in the family-owned businesses researches, such as ex.: economics, anthropology, finance, sociology, management, psychology, organizational behavior or accounting [Niedbała 2003, p.44]. Therefore, the definitions of the family-owned businesses are embedded in theoretical systems derived from the others, mentioned above academic fields. The social approach took its starting point from the social bonds as a main organizational binder. Others, based on the resources (Resources-based Theory) determine the family-owned businesses through the prism of its resources, which include impact of the specificity of the family-owned business financial resources and physical resources (in the context of the property). They can be used as an enterprise support. It is also distinguished the personal resources (in the context of an exercise the authority) and also the social capital arising from the relations 
a certain enterprise is creating with employees, clients, suppliers and widely understood environment. The other, most developed approach, join economic and social attribute of the family-owned businesses. It is defined as integrated, as it is trying to connect in the one model the issues related to the family and the business sphere of the enterprise and reviling the interrelations between them. In this approach the enterprise towards the family is a base and the center of the family life and it impacts the family members lives. In the other hand, the family towards the enterprise is an initiator of its creation and development and above all, it stands for its existence. Therefore a family-owned business is define as: "the enterprise managed by use of family ownership supervision and/or managers with intention of creating and/ or continuing a vision of the enterprise by dominating coalition, which are controlled by the members of one or few families in such a way, that it allows its potential maintenance of the vision between the family or families generations" [Chua, Chrisman, Sharma, 1999, p.23].

In the literature can be found the chosen list of the characteristics, "possession" of which, in the most comprehensive manner describes a specificity of the familyowned business. Amongst them is located existence of the so-called feedback loop between the family and the enterprise. It is said most often about a lack of significant distinction between them, what is particularly evident in the small entities. This feedback determines the manner of functioning, so it impacts the management of a certain enterprise. Most of all, the family members take the crucial position or hold the decision majority in regards to the company management control. The family-owned business specificity is also determined by the system of values, priorities and goals, which in the same time determine all operator's activities and the philosophy of the enterprise. The condition for "familiness" of the enterprise is also the fact, that in the company works more than one member of the family. The fact of possessing by the family an enterprise can impact the decisions of choice of the professional life direction for the next generation. An external system of the family relationships often also decides about who will be taken into consideration in the matters of succession and taking over the management and ownership of the enterprise or its assets.

Characterizing family-owned businesses the authors also attempt to identify those characteristics, which distinguish them from non-family-owned businesses. One of the aspects is, for example, that the features related with the company development may not harmonize with current ownership structure. Together with the foreign expansion or enlargement of the products range may occur a need to obtain an additional financial sources ex. stock issues. Then may occur one or more new owners, what sometimes can result in control acquisition (control package) or even by not desirable persons or institutions ${ }^{2}$.

2 An example of such hostile takeover can be a case of KRUK, which was bought by the Vistula. However, the actions taken by the owner of the hostile acquired company allowed to return it in the 
Another feature distinguishes family-owned businesses from the non-familyowned ones is that in the first type the more important is long-term security then the short-term pursuit of profit. Welsch (1991) in 1991 compared the results of the researches conducted in Spain by Gallo and Pont, in Germany by Wieselhuber and Spannag and in Great Britain (research team of Stoy Hayward). The researches has shown, that the family-owned businesses are older than non-family-owned ones, and that management period longitude of the main manager is also longer in the family-owned businesses than in non-family-owned ones. The impact of the family factor may determine a competition superiority of the family-owned business, due to an existence of the consequent, coherent and long-term strategic goals. This, in turn diminishes importance and pressure only on short-terms benefits. The family culture, and in consequence the culture of the company makes the employees to be surrounded by a larger concern and the owners demonstrate a larger responsibility towards them and the nearest society. This strong culture and family values provide a certain stabilization, which may release in the employees a sense of unity and loyalty, and in consequence strengthen their motivation and engagement. The external business image is created by the family or families system of values [Safin 2002, p. 36-40]. This, in turn impact a larger responsibility, due to identification the business with the family. The family-owned companies characterized with the larger flexibility and resistance to the periods of economic downturns ${ }^{3}$. This is due to the willingness to provide the family existence and maintaining continuity of an ownership. Despite the fact, that family-owned businesses distinguish each other with the size, trade field etc. they possess one common feature distinguish them from the other businesses. In the family-owned enterprises the family, business and property are interdependent and infiltrate each other. In 1982 Tagiuri and Davis (1982) have presented a model showing the family-owned business as a system of three circles, which included as follows: family, business and property (picture 1). Every of the mentioned subsystem is to be described as an independent link, nonetheless maintained in the very tight relation. Every family member plays the one or a few roles, which means that he may be only an owner or simultaneously an owner, a family member or a family member and investment manager [Cohn 1992, p.32].

family hands.

3 These results are taken from the third Stoy Hayward report in 1992 and the framework program "Management of the Family-owned Business in UK". 


\section{Picture 1. Systems of the family-owned business.}

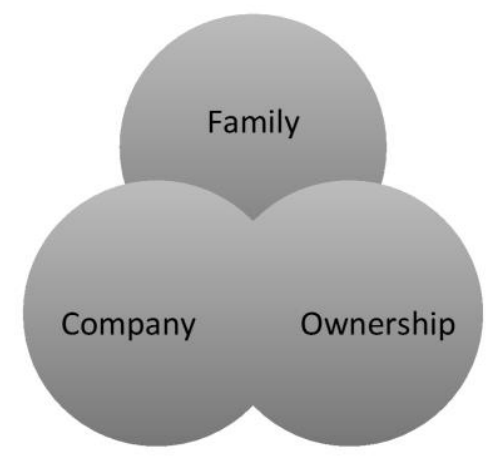

Source: Cohn 1992, p.32.

The family subsystem includes the individual family members, often the next generations. The relations are based on feelings and emotions and the system is oriented on providing the security, calmness and internal harmony. In other words, the system is being focused on the members of the family. The enterprise subsystem, so-called economic subsystem includes employees, managers and clients. Its task is to accomplish the enterprise goals, thus it should be external orientated on clients (assuming the company marketing orientation). The property subsystem is created by all enterprise owners, including family members, both active in the ongoing business and those passive due to their age (but with the decision voice still meaningful) and the company co-owners outside of the family. This subsystem determines a strategic management, creates a mission and a vision. The overlapping areas are the fields predisposed to the arising conflicts. This is due to the fact, that the rules and expectations in every subsystem differ each other and at times remain in a conflict. For example, in the family subsystem remuneration is measured by a need, whereas in the enterprise subsystem remuneration includes activities and its efficiency [Jaffe 1990, pp. 27-36]. Habbershon and Williams [1999] using the resource-based theory show that in the family-owned businesses the family, its resources and abilities so-called "familiness" may generate competitive advantage. The "familiness" is a concept refers to a family with its unique set of resources, which arise from the interactions, the business, the family as a whole and the individual family members. These included engagement of the family, both formal and informal in the ongoing strategic activity of the enterprise. It can be measured by use of the family members in the decision process and also by the number of the generations working in the company. The special feature arises from the family engagement is a willingness to maintain a control over company in the family hands. The control is to provide the enterprise existence for the next generations. 
Another resource arises straight from the family-owned business character is the system of values in the enterprise. This system is often a calque of the family system of values. In the case of the family-owned enterprises economic values coexists with the family, moral and often religious and the others values. All decisions taken in the enterprise are dominated by the family welfare, which is the most important factor. The enterprise is treated as a very important element of the family life, as it provides means for survival, and also simultaneously may be the center of family functions, and unite it around the common issues. The important feature of the enterprise system of values is pursuance to minimize the risk and omitting the short-term speculations activities. The family-owned businesses possess a long-term perspective of activity, which allows the actions in the more stable conditions. The feature of the family-owned business is a pursuance to maintain an independence. Emotional approach is also a characteristic that specifies the family-owned business system of values. Not without significance is the fact, that on the one hand familyowned businesses tend to be rather hermetic ex. towards to generally understood cooperation with other companies or employees outside the family, and on the other hand they are very sensitive to the relationship with the local community. The family-owned businesses system of values may be divided to the two different co-existing with each other dimensions: internal, so-called organizational culture of the enterprise and external including reputation, renown, and good name of the company. The set of the crucial factors includes also a resource of the knowledge (especially knowledge arisen from an experience). Widely understood knowledge resource is thought to be one of the most important resource in every enterprise. In the family-owned business it is based on an experience and tradition, which are thought to be so-called a hidden knowledge, difficult to reach for competitive companies. The list of the family-owned business internal factors includes also a special kind of confidence, which exists between family members, employees and also in relation with an external environment. In the family-owned business the values and family needs are co-existing together with the reality of the economic entity, which results in arising significant differences between family-owned businesses and non-family ones, especially, that the family and business goals are often incompatible [Fridman 1991, pp. 3-20].

\section{Family-owned business organizational culture and national culture}

The family-owned businesses are dominating in the most of the world economies, they are source of the enterprise development, however, not many worldwide researches take into consideration the cultural factor [Brice, Richardson 2009, p. 246; Vallejo 2008, p. 261].

In one of the national culture definitions distinguishes its components is stating, that: 
"the culture is the accumulation of the shared meanings, rituals, norms and traditions among the members of the community. It is something that characterizes the human community its individuals, social organizations, and also economic and political systems. It includes both abstract ideas such as values or ethics and material objects or services, such as cars, cloths, food, or art and sport, which are manufactured or valued in a group of people (society)" [after: Bartosik-Purgat 2011, p. 27]. It is need to notice, that between national culture and culture of the enterprise exist many common areas.

The substance of the relationship between national culture and organizational culture arises from the singularity of the organizational culture. It is due to characteristic of the enterprise system of processes, which join preferred by the management board and employees social and cultural values and norms with their bases and approaches, in which these attitudes create the organizational behaviors. The elements of the organizational culture include these, which are observed to have significant influence on the national culture factors, these are, amongst others: values, language, symbols, rituals [Gorynia, Bartosik-Purgat, Jankowska, Owczarzak 2005, p. 113-114].

In the literature on family-owned businesses there are mentioned two main elements of the organizational culture impact the structure and functions of the family-owned businesses, namely the family goals and the values. These family goals include encouraging and supporting the family members to co-create an organization and common contribution in gaining a profit. The studies showed, that in a number of decisions relating to the family-own companies (strategic, financial) the family needs are taken into consideration. Leenders and Waarts called this family-owned businesses feature as a "family orientation" [Leenders, Waarts 2003, p. 687]. The values impact, in turn, the dynamics of the family-owned businesses, creating bounds of the confidence and loyalty, which determine extremely valuable feature, at times impossible to gain in the "non-family-owned" companies [Brice, Richardson 2009, p. 248]. Both values and goals are determined by the familyowned businesses founders. In the situations, where are observed very strong family relations the next generations protect these values, often considering them as a mission and the main challenge of the company. The founders effects are continued for a long time especially in small and middle-sized operators, which is indicated by the results of empirical researches conducted in companies such, as Akdogana and ve Mirapa [Erdem, Başer 2010, p. 49]. The similar conclusions were reached by Sonfield and Lussier conducting their researches in the family-owned businesses, in which were working three next generations. The reason of the founders goals continuation is a family impact and the strength of the family-owned business system [Sonfield, Lussier 2004, p. 198]. In turn, Davis and Harveston stated, that the basic assumptions, activities and approaches in family-owned businesses functions change together with the managing generations [Davis, Harveston 2001, s. 25]. The 
authors believe, that the differences between generations impact mainly the variant approach in conducting business.

In the most of the family-owned businesses the founders are those who form its organizational culture, which is based mostly on confirmed by themselves values and cultivated customs [Erdem, Başer 2010, p. 48; Klein, Waxin, Radnell 2009, p. 46; Van Oudenhoven 2001, p. 105]. The organizational culture is a transporter of values and norms shares by the participants in the organization, which are components of their national cultures. The values and customs are acquired and learned most often in the family homes. The whole of the cultural canon is being installed in the youngest community members in the acculturation process by the family and external environment [Jaw, Ling, Wang, Chang 2007, p. 128-144; Lyman 1991, p. 305]. The family values, in turn are determined also by the features of the national culture, in which these people were raised. Therefore it may be stated, that the national culture has an indirect (with the help of companies founders, members of a certain nation) impact on a family-owned business functions, the accepted principles, rituals, communicational approaches and other elements of the organizational culture (picture 2).

Figure 2. Relation between the national culture and the organizational culture in the family-owned businesses.

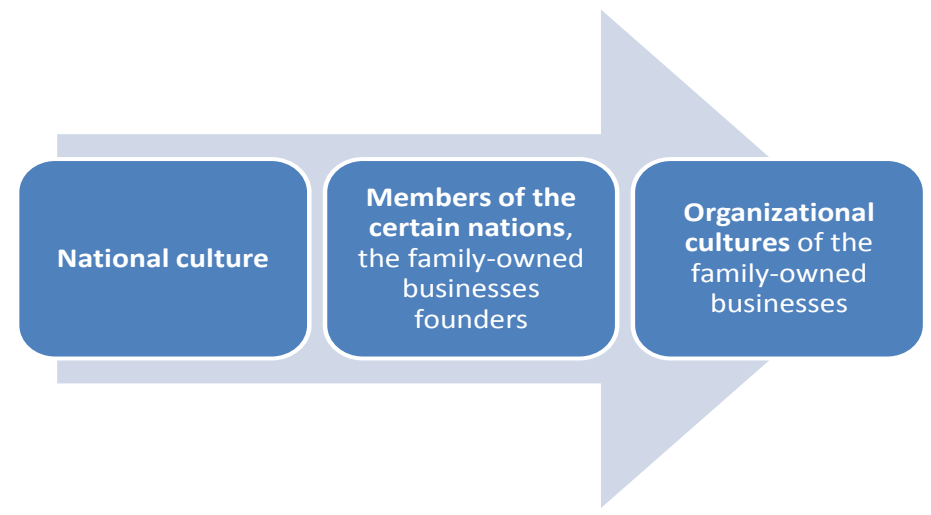

The national culture impact the organizational culture of the companies implies them the certain features characteristic for given community. Below are presented results of the researches conducted in the discussed area in the many countries and cultures. The following analysis is to attempt to isolate the cultural factor, in the view of existing classifications and cultural theories, which may differ with a character, a structure and functions of the family-owned businesses on the international scale. Above this, it was decided to analyze the impact of the family-owned businesses specificity on the distinguished cultural features. 
After detailed reading of the presented field literature it was decided to select a certain dimensions - cultural features, which are especially characteristic and noticeable in the family-owned businesses, namely:

- Universalism versus particularism, according to Trompenaars and HampdenTurner,

- Achievement versus ascription, according to Trompenaars and HampdenTurner,

- Distance of power, according to Hofstede,

- Masculinity versus femininity, according to Hofstede,

- Relationship-focused versus deal-focused, according to Gesteland.

Universalism - particularism is a cultural dimension differ the countries with their enterprises in the area of perception and interpretation of the existing rules, customs and norms. In some of the countries the procedure is always the same according to the generally accepted principles, specific standards regardless of the nature of the given situation. These are the cultures specified in the Trompenaars and Hampden-Turner's researches as universalistic and these include among others: Switzerland, Sweden, and Great Britain. In the countries with the opposite attitude given behavior or decision is considered from the viewpoint of the situation. It is taken into consideration the circumstances appeared, which ex. we could not to proceed according to the generally accepted rules. The authors specify these cultures as particularistic and these include: Greece, Venezuela, and Russia [Trompenaars, Hampden-Turner 2002, p. 48].

In the view of Adams, Taschian and Shore study the family-owned businesses in general does not formalize the proceeding codes in the organizations, although they are tend to establish standards of behavior using the models of the family roles. In addition, assessing the specific situation and solving the problem it is often rather a given circumstances taken into consideration then accepted procedures [Adams, Taschian, Shore 1996, p. 162]. Therefore it may be concluded, that "familiness" in this type of enterprises may weaken a universalistic tendencies. In other words, compering family-owned businesses and no-family-owned businesses (even from the universalistic country) these firsts more often may show particularistic features in relation to given situation (picture 3). This is due to the fact, that "familiness" impact advantage of particularistic behaviors not only in the particularistic societies, but also in those with universalistic attitude.

The important cultural factor impact the enterprises organizational structure are differences related with the perception of inequalities between subordinates and superiors. This dimension has been distinguished by Hofstede and define as a "distance of power" relied on the relationships existed between elderly and young family members (ex. parents and children), as well as persons occupying different positions in the organization. In the culture characterized with a large "distance of power", the decision is usually taken by the elderly, ex. parents, or being higher in 
the hierarchy (those "having more power"). The parents are authorities for their, often adult, children, granted deserved respect and impact decisions taken by them. An example of large "distance of power" countries are: Malaysia, Guatemala, Panama, Philippines, Mexico, Venezuela, Saudi Arabia, India, Spain, Italy. In turn in the opposite cultures from the viewpoint of the "distance of power" an influence on decisions have not only persons, which are on the highest level in the family hierarchy or organization (enterprise). Into consideration are taken opinions all the members/ representatives, which participate in talks, the consequence of which is to take appropriate decisions. The representatives of this culture type are: Austria, Denmark, New Zealand, Ireland, Sweden, Norway, Finland, Switzerland, Germany, Great Britain, Holland, Australia [Hofstede, Hofstede, Minkov 2010, pp. 23-47; Harvey 1997, p. 137].

Figure 3. Impact of the family-owned businesses specificity on the particularistic and universalistic behavior.

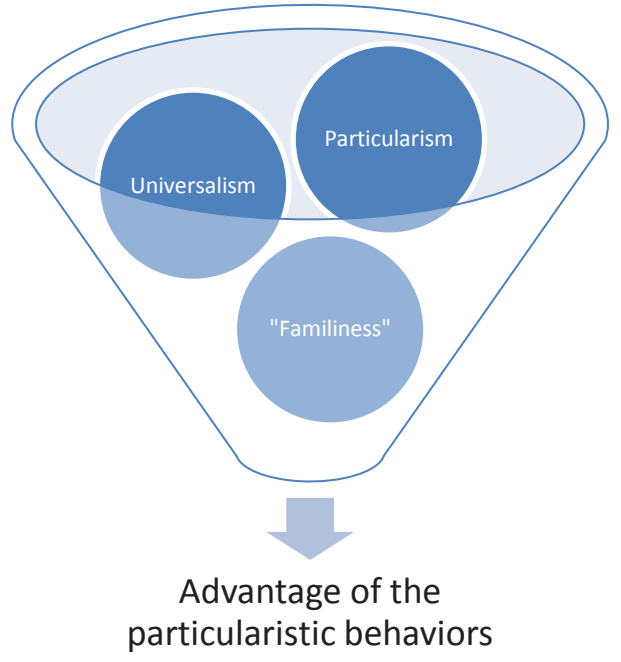

Source: own study

The study of Kets de Vries shows, that the family businesses founders and their successors are usually reluctant to delegate power and decisiveness on persons from the outside of the closest circle. It is observed a management centralization with the unidirectional flow of information from the management to the employees [Kets deVries 1996, s. 63]. An example may be Spanish or Italian family-owned businesses, in which the most important person is father, usually the company founder or his successor, who enjoys a great respect amongst his adult children, and who usually also work in the company. Poza, Alfred and Maheshwari also showed in their report, that taking decisions in the family-owned business is centralized and concerns the 
main members of the founding family [Poza, Alfred, Maheshwari 1997, p. 140]. This would indicate an occurrence of differences between the employees in the family-owned organizations and existence the hierarchic structures. In other words "familiness" may impact increase of the "distance of power" rate. Therefore a specificity of the family-owned businesses may cause, even in the countries with relatively low "distance of power" occurring a hierarchy and differences between individuals in the organization. Similarly, the results of Brice and Richardson studies (2009), conducted in Ukrainian and American family-owned businesses and those not belonging only to the one family, showed, that in the family-owned businesses "distance of power" rate is higher than in the non-family-owned businesses. On the Ukrainian market it was a little higher than in the American market. It is also shown by Rao's analyses conducted in the Mexican family-owned businesses, in which hierarchy is intensified by paternalism of the Mexican culture [Rao 2009, p. 298]. This situation in the Mexican businesses confirm studies conducted by Athanassiou, Crittenden, Kelly and Marquez (2002, p. 140), in which emphasized are multigenerational businesses conducted and managed by successive generations the founders successors. These are hierarchical, however relations occurring inside them reminds the situations in many of the traditional families, in which the most important and the last word belongs to the head of the family (father or mother), who is taking care of all its members. Similarly in the Mexican family-owned businesses the authors perceive the family relations, which is hierarchy and focusing on an employee and his needs. Also features of the Arabic culture related, on the one hand, with a rigid allocation of roles, paternalism, hierarchy, and on the other hand with confidence and importance of the interpersonal relations, which all impact the fact, that the representatives of those cultures find themselves better in the local familyowned businesses than in the international corporations. Therefore it appears, that the features listed above characterized family-owned businesses regardless of in which corner of the world they were created, wherein in some countries they occur with a greater intensity [Calza, Aliane, Cannavale, 2010, p. 249]. Kim and Gao studies also confirm above mentioned statements and show increased hierarchy and family impact on the business activity in the Chinese family-owned businesses. These studies shown, that in the Chinese family-owned businesses exists very large differences between positions (rank) of the superiors and subordinates. Chinese culture belongs to those characterized by, in the light of Hofstede's dimensions, with a large "distance of power", in which almost all the important decisions in the company are taken at the highest levels of the organizational structure [Kim, Gao 2013, p. 270]. Concluding it is need to repeat, that specificity of the family-owned businesses impact increasing hierarchy and differences between the managing (most often the owners) and the subordinates. Even in the societies characterized by a small "distance of power", compering family-owned and non-family-owned 
businesses, in those firsts above mentioned features are more common and more visible.

Figure 4. Impact of the family-owned businesses specificity on the behaviors connected with hierarchy in the company.

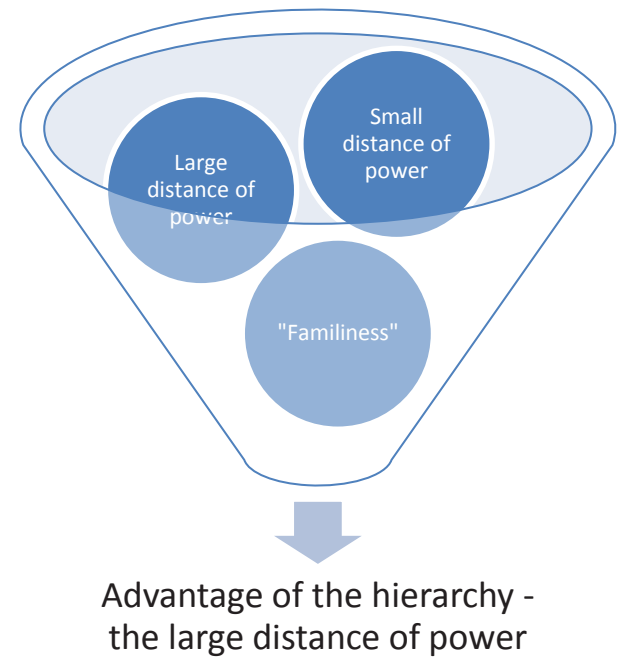

Source: own study.

Above were presented cultural features of the family organizations connected with the hierarchy, but also involving treatment of the employee almost as a family member, even if he is not. This attribute is particularly noticeable in the cultures described by Gesteland as the pro-partnership. Describing these cultures, the author turns attention on the persons not only tasks, effects, gaining a profit etc. In the pro-partnership countries important are relations between persons cooperating, it is preferred to keep the contacts with the family, friends, or wellknown individuals, these which are worth of trust. Amongst pro-partnership countries it may be distinguished most of the Asiatic, Arabic, African and Latin American countries. In turn, the societies oriented on quick tasks execution, and attaining goals are specified as pro-transactional. For this type the most important is transaction and its successful completion for trading profit, on the beginning without paying attention to wide degree of knowledge about the partners. Protransactional cultures include, inter alia, United States, the Scandinavian countries and other Germanic European countries, Australia, New Zealand [Gesteland 2001, pp. 20-22]. In the family-owned businesses dominating attitude is pro-partnership one, which it is shown even in the countries known as pro-transactional (picture 5). 
Figure 5. Impact the specificity of the family-owned businesses on the degree of the pro-partnership/ pro-transactional behaviors.

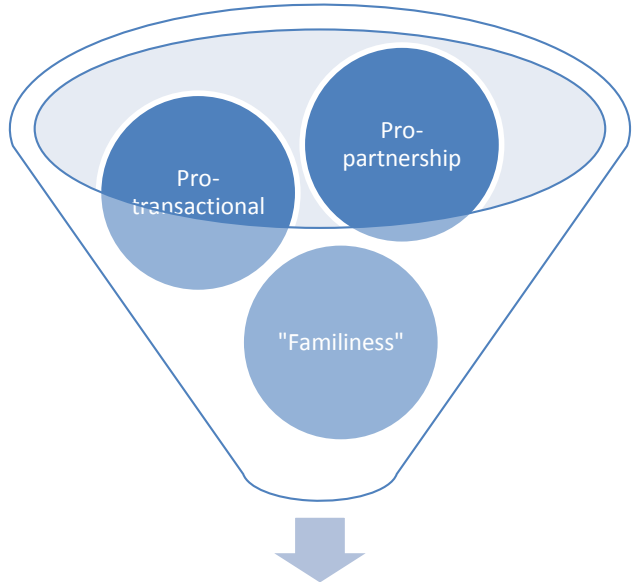

\section{Advantage of the pro- partnership attitude}

Source: own study

A cultural dimension having a large importance in forming organizational structures in the companies is masculinity - femininity, which refers to the existence of the masculine or feminine advantages. It is mainly reflected in the values accepted by the members of the organization, certain behaviors or roles performing by them. For example, in the masculine cultures popular are such features, as activity, aggression, implementation, permanent competition and conquering. The feminine cultures are characterized, most of all, by tenderness and protectiveness in the wide spectrum of meaning of these words [Hofstede, Hofstede, Minkov 2010, pp. 79-105].

According to Schulze and others, the family-owned businesses are characterized by altruistic values, their members care more about prosperity and quality of life [Schulze, Lubatkin, Dino, Buchholtz 2001, p. 104]. Referring to Hofstede's (2010) cultural dimensions such features could indicate femininity of these companies, which is connected with emphasizing quality of life and not its material dimensions, what is count is willingness and not only success and competition, those who fail are getting help, "one work in order to live" and not "one live in order to work" (the masculine dimension). The views of the Schulze and his cooperators were confirmed in the studies conducted by Brice and Richardson amongst the group of the Ukrainian and American family-owned businesses, in which the feminine values rated much higher than in the non-family-owned ones [Brice, Richardson 2009, p. 258]. The specificity of the family own businesses impact the emphasis of 
the feminine values regardless of which environment, feminine or masculine the company conduct its activity (picture 6).

Figure 6. Impact of the specificity of the family-owned businesses on the domination masculine or feminine features in the organization.

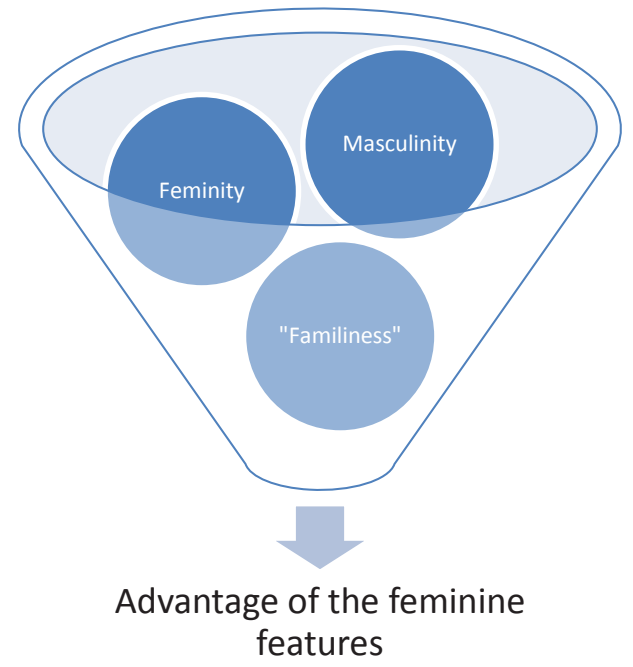

Source: own study

The studies of Trompenaars and Hampden-Turnera conducted in the differential culture environments showed also, that there are differences in regards to the methods of obtaining the status in the community or company. They distinguish countries, in which the status and given position are granted persons in exchange for goals they achieved (ex. Norway, Denmark, Finland, Great Britain, United States, Sweden, Canada, Australia, France) and those, in which the status is granted ex. due to the age, class affiliation, gender, or possessing certain connections (here status refers mainly to who the person is, ex. Kuwait, Saudi Arabia, Thailand, India, Philippines, Kenya, Argentina) [Trompenaars, Hampden - Turner 2002, pp. 126-145].

The analysis of the family-owned structures shows described above behavior as a "status assigned", wherein the status in the company is granted mainly in the view of family connections. It is especially noticeable in the countries with the assigned status. However, also in the countries with the status achieved "familiness" in the business impact ex. occupation the position only due to the family connections (picture 7) [Rao 2009, p. 297]. 
Figure 7. Impact the specificity of the family-owned businesses on the domination of the status achieved or assigned.

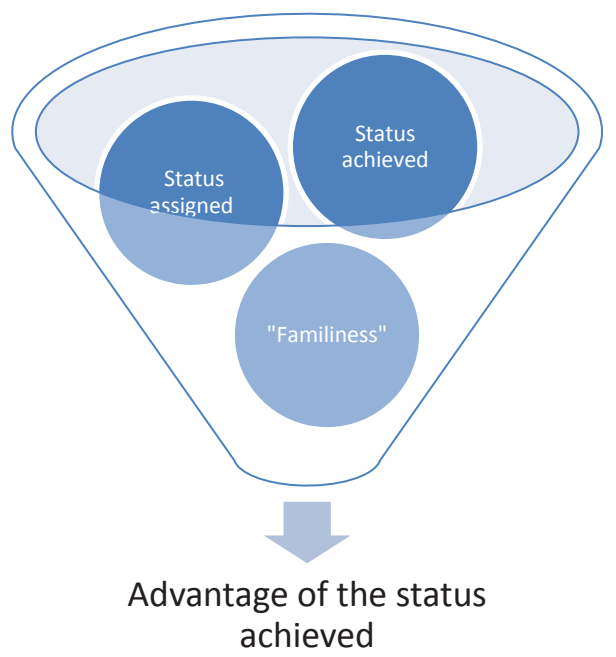

Source: own study

\section{Conclusion}

Concluding above theoretical analysis, it must be stated, that the "familiness" is the factor, which impact the force of occurring in the family-owned organizations certain features arising from the national culture of given country. Below table 8 presents collected relations of the force of occurring certain (chosen) cultural features in the family-owned business and impact of the specificity of the familyowned businesses (so-called "familiness").

The studies conducted by various authors in the international arena (in various markets and differential cultures) tend to conclude, that the "familiness" of these entities has a significant impact on the features of the organizational family-owned businesses. These studies also show, that "familiness" of these entities determines specified behaviors even if they function in the market characterized with the advantage of another cultural features. In other words it may be stated, that the family-owned businesses, regardless to the country, in which they function, possess the common features. They occur with the more or less force in the given market, which can be related with its cultural influences. Theoretical analysis conducted in the paper gives the framework to empirical research. Crated above model needs to be verify. 
Figure 8. Impact of the "familiness" on the cultural features advantage in the organizational structures of the family-owned businesses.

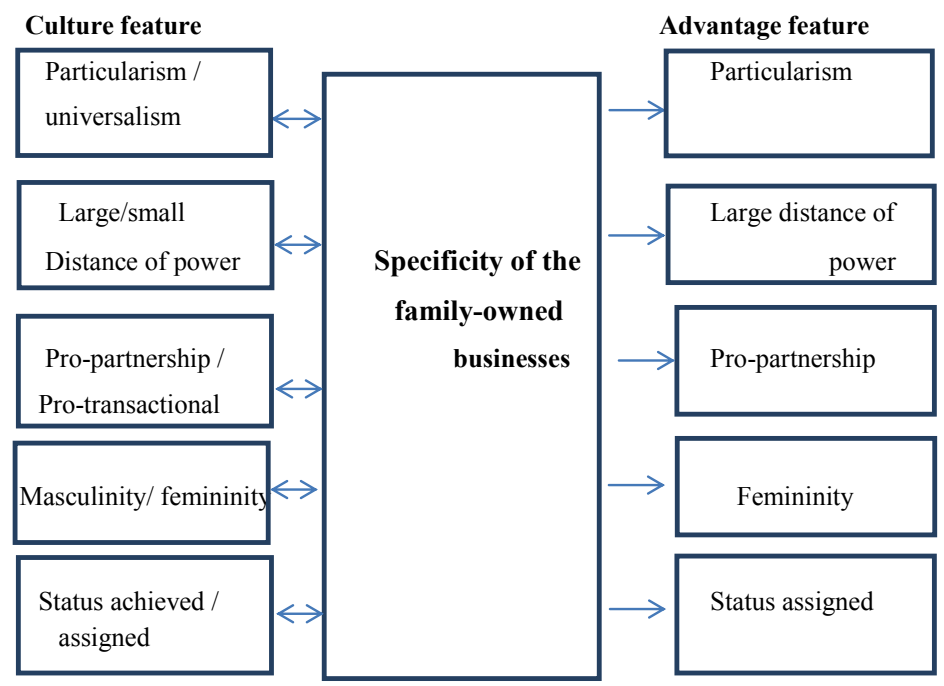

Source: own study

\section{Bibliography}

Adams, J.S., Taschian, A., Shore, T.H., [1996], Ethics in family and nonfamily owned firms: an exploratory study, "Family Business Review", Vol. 9 No. 2, pp. 157-170.

Athanassiou, N., Crittenden, W.F., Kelly, L.M., Marquez, P., [2002], Founder centrality effects on the Mexican family firm1s top management group: firm culture, strategic vision, and goals and firm performance, "Journal of World Business", 37, pp. 139-150.

Bartosik-Purgat, M., [2011], Kulturowe uwarunkowania zachowań konsumentów na przyktadzie młodych Europejczyków, Wyd. UEP, Poznań.

Brice, W.D., Richardson, J., [2009], Culture in family business: a two-country empirical investigation, "European Business Review", Vol. 21 No. 3, pp. 246-262

Calza, F., Aliane, N., Cannavale, Ch., [2010], Cross-cultural differences and Italian firms' internationalization in Algeria. Exploring assertiveness and performance orientation, "European Business Review", Vol. 22 No. 2, pp. 246-272

Chua, J.H., Chrisman, J.J., Sharma, P., [1999], Defining the Family Business by Behavior, "Entrepreneurship Theory and Practice", Vol.32 No. 4.

Cohn, M., [1992], Passing the Torch, Succession, Retirement, Estate Planning in Family - Owned Business, McGraw-Hll, Inc, New York.

Davis, J.A., Stern, D., [1980], Adaptation, survival, and growth of the family business: An integrated system perspective, "Human Relations", No. 34. 
Davis, P.S., Harveston, P.D., [2001], The phenomenon of substantive conflict in the family firm: a cross-generational study, Journal of Small Business Management, Vol. 39 No. 1, s. 14-30

Erdem, F., Başer, G.G., [2010], Family and business values of regional family firms: a qualitative research, "International Journal of Islamic and Middle Eastern Finance and Management", Vol. 3 No. 1, pp. 47-64.

Friedman, S.D., [1991], Sibling Relationships and Intergenerational Succession in Family Firms, "Family Business Review", No. 4.

Gesteland, R.R., [2001], Cross-Cultural Business Behavior. Marketing Negotiating and Managing Across Cultures, Copenhagen Business School Press, Copenhagen.

Gorynia, M., Bartosik-Purgat, M., Jankowska, B., Owczarzak, R., [2005], Strategie firm polskich wobec ekspansji inwestorów zagranicznych, PWE, Warszawa.

Habbershon, T.G., Wiliams, M.L., [1999], A resource-based framework for assessing the strategic advantages of family firms, "Family Business Review", Vol. 13, No. 1.

Harvey, F., [1997], National Cultural Differences In Theory and Practice. Evaluating Hofstede's National Cultural Framework, "Information Technology \& People", Vol. 10 No. 2, s. 132-146.

Hofstede, G., Hofstede, G.J., Minkov, M., [2010], Cultures and Organizations: Software of the Mind. 3rd Edition, McGraw-Hill USA.

Jaffe, D.T., [1990], Working with ones you love: Conflict resolution and problem solving strategies $f$ or a successful business, Barkeley, CA, Conari.

Jaw, B-S., Ling, Y-H., Wang, Ch. Y-P., Chang, W-Ch., [2007], The impact of culture on Chinese employees' work values, Personnel Review, Vol. 36 No. 1, pp. 128-144

Kets de Vries, M., [1993], The dynamics of family controlled firms: the good and the bad news, "Organizational Dynamics", Vol. 21 No. 3, pp. 59-71

Kim, Y., Gao, F.Y., [2013], Does family involvement increase business performance? Family-longevity goals' moderating role in Chinese family firms, "Journal of Business Research", No. 66, s. 265274

Klein, A., Waxin, M.F., Radnell, E., [2009], The impact of the Arab national culture on the perception of ideal organizational culture in the United Arab Emirates, Education, "Business and Society: Contemporary Middle Eastern Issues", Vol. 2 No. 1, p. 44-56

Leenders, M., Waarts, E., [2003], Competitiveness and Evolution of Family Businesses: The Role of Family and Business Orientation, "European Management Journal", Vol. 21, No. 6, pp. 686-697

Lyman, A.R., [1991], Customer service: does family ownership make a difference?, "Family Business Review", Vol. 4 No. 3, pp. 303-324

Niedbała, E., 2003, Firmy rodzinne - obieket badawczy, MBA 2003 nr 5.

Pant, P.N., Rajadhyaksha, V.G., [1996], Partnership with Asian family business - what every multinational corporation should know, "Long Range Planning”, Vol. 29 No. 6, pp. 812-820.

Poza, E.J., Alfred, T., Maheshwari, A., [1997], Stake-holder perceptions of culture and management practices in family and family firms - a preliminary report, "Family Business Review", Vol. 10 No. 2, pp. 135-55 
Rao, P., [2009] The role of national culture on Mexican staffing practices, "Employee Relations", Vol. 31 No. 3, pp. 295-311

Safin, K., [2002], Zarzqdzanie mała firma, AE, Wrocław.

Schulze, W.S., Lubatkin, M.H., Dino, R.N., Buchholtz, A.K., [2001], Agency relationships in family firms: theory and evidence, "Organization Science", Vol. 12 No. 2, pp. 99-116.

Sonfield, M.C., Lussier, R.N., [2004], First-, second-, and third-generation family firms: a comparison, "Family Business Review", Vol. 17 No. 3, pp. 189-202

Trompenaars, F., Hampden-Turner, Ch., [2002], Siedem wymiarów kultury, Oficyna Ekonomiczna, Kraków.

Vallejo, M.C., [2008], Is the culture of family firms really different? A value-based model for its survival through generations, "Journal of Business Ethics", Vol. 81, pp. 261-79.

Van Oudenhoven J.P., [2001], Do organizations reflect national cultures? A 10-nation study, "International Journal of Intercultural Relations", 25, pp. 89-107

Zellweger, T.M., Astrachan, J.H., [2008], On the emotional value of owning a firm, "Family Business Review", Vol. 21 No. 4, pp. 347-63. 